\title{
EFL Young Learners' Problems Encountered in the Learning of English Speaking: Teachers' Perspectives
}

\author{
Nur Syafira Nikmah, ${ }^{1}$ Choiril Anwar ${ }^{2 *}$ \\ 1,2 Universitas Islam Sultan Agung, Semarang, Indonesia \\ *) Corresponding Author \\ Email choirilanwar@unissula.ac.id \\ DOI: 10.18326/rgt.v14i2.301-316 \\ Submission Track: \\ Received: 29-09-2021 \\ Final Revision: 22-11-2021 \\ Available Online: 01-12-2021
}

Copyright $(92021$ Author(s)

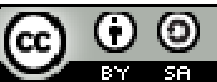

This work is licensed under a Creative Commons Attribution-ShareAlike 4.0 International License.

\begin{abstract}
Teaching speaking to Indonesian EFL young learners is still problematic. It happens not only because English is not used in daily activities but also the government's regulation to some extent does not support that. This qualitative study aims to describe the problems faced by EFL students in the learning of English speaking with teachers' perspectives. The samples of this research were three teachers from three different elementary schools in Jepara, Central Java, Indonesia. The data were collected using questionnaires, interviews, and classroom observations. The data were then analyzed by 1) memoing or transcribing the interview data, reading them to make notes and finding the most important information that might be useful for the study, 2) describing the data to find complete explanation of the context, setting, and interactions of participants, 3) classifying the data to break down the obtained result and put it into categories, and 4) interpreting the data to find the meanings of the data by connecting the findings with previous studies, personal experience, and expert advice to find the best result. The result showed that EFL students' problems in the learning of English speaking came from some factors. They are 1) Native language, 2) Age, 3) Exposure, and 4) Motivation, and 5) Learners' Autonomy.
\end{abstract}

Keywords: speaking; Indonesian EFL students; young learners

\section{INTRODUCTION}

There have been actually plenty of previous studies regarding the improvement of EFL elementary students' speaking skills. The relevant studies 
were conducted by Ramadhani (2017), Widodo and Dewi (2019), and Abrar (2016). Those studies mostly underlined the teachers' issues in teaching speaking to young learners. The problems were most related to the classroom and time management, ability to give feedback, and teachers' ability to diagnose difficulties faced by the learners. However, certain speaking learning issues focused on the students' sides via their teachers' perspectives have not been studied in detail.

Some schemata and facts become the other reasonable research backgrounds for choosing this topic. The improving era towards the industrial revolution 4.0 increasing rapidly requires adaptations to be relevant with future demands. To be able to survive in this modern life, it is obvious that human resources with a high level of knowledge and competence are needed. As stated by Nofrion (2018), the ability to think critically, creatively, innovatively, and having qualified communication ability are the main skills that are needed to deal with the modern era. Qualified communication ability becomes very important for the children in the next generation because in the future what they will face is the great development of the world. In conducting communication in the global era, competence in mastering the English language is essential (Samosir et al., 2017).

Moreover, teaching English could be successful if the four language skills are integrated in an effective way (Sadiku, 2015). As one of the skills in English learning, speaking is one of the productive skills, which need regular practice and habituation. It is really important because it is the main skill to communicate (Nuraini, 2016). The teaching of foreign languages, particularly speaking, should be done from an early age (Arif, 2017) considering that children in the younger age tend to have higher chances to develop their knowledge and skill. They have a clear brain that allows them to easily receive the language inputs from their teacher (Nihat, 2010). In line with the statement, Maili (2018) mentioned several international studies showing that children improve critical thinking skills, creativity, and flexibility of mind by learning foreign languages.

Primary school period is the right time to introduce English to children because it is the golden period for children's language development. There has not been a separation process on children's right and left-brain functions, so 
they will easily accept language inputs. Children easily receive foreign language exposure as well as their mother tongue, have more capability in learning another language, and have different stage of physical, psychological, social, emotional, conceptual, and cognitive development, as well as their development of literacy (Ellis (2014). Therefore, it will be very unfortunate if this period goes by untapped.

Unfortunately, in Indonesia especially in the three elementary schools observed in Jepara, teaching English speaking for students of young learners was still problematic. Students could not speak in the English language even only in short simple conversations. Students were shy to show up saying something to their teammates and teachers in English.

The regulation of the 2013 Curriculum claims that English is no longer the compulsory subject for Elementary School. Based on Permendikbud No. 67 of 2013 concerning the Basic Framework and Structure of the Elementary School/ Madrasah Ibtidaiyah Curriculum, English language is recently regarded as a local content subject at some private elementary schools and only as an extracurricular activity at state public schools. The changes from English as a compulsory subject to local content reduce the time for English lessons. The current ministry of education has also supported this policy. It is unable the teacher to teach English to young learners, especially the speaking skill because it needs a long learning process. For some elementary schools, holding English as their local content subject, it can be said that the learning process in teaching speaking for young learners still faces many failures. Those failures can be perceived from the outputs or graduates. Many students cannot speak well even for simple daily conversations.

Young learners need more time to listen to a foreign language and they also need more chances to practice some of the words and sentences in order to learn how to speak the language. Nevertheless, teaching speaking for young learners is not as difficult as it seems (Ramadhani, 2017). Children absorb everything the teacher says and how the teacher says it. Since they will repeat what they exactly hear, teachers should apply some rules in teaching. They should give continual and constant repetition, creating a relaxed and positive classroom atmosphere, using various teaching methods, and giving as many 
chances as possible for the learners to practice pronouncing and speaking English either in the classroom or outside the classroom. Thus, learners' speaking and communication skills will be improved and they can express themselves and take part in the social and cultural rules.

Teaching speaking for young learners is completely different from teaching speaking for adults. It is really important for teachers to use various methods, techniques, and activities, which can involve students' participation in class. According to Pratama (2015), there are two methods that commonly used to teach English speaking to EFL young learners namely Audiolingual Method (ALM) and Communicative Language Teaching-CLT (Nuraini, 2016; Ohashi, 2015). Various forms of drills (Backward Build-up Drill, Repetition Drill, Chain Drill, Single-slot and Multiple-slot Substitution Drill, Transformation Drill) in ALM can be applied (Khetaguri \& Albay, 2016).

In CLT, the teacher acts as the facilitator in setting up communication activities. He/she is responsible for building situations, giving advice, and monitoring students' performance. While the students are obviously the communicators, they cooperate and collaborate with their friends as well as being responsible for their own learning process (Freeman \& Anderson, 2011). Some techniques that are closely related to CLT in improving speaking skill for young learners according to Freeman and Anderson are: Picture Strip Story (Novianda, 2017), Role-play, Show and Tell (Anwar, 2016), and Language Games (Zhu, 2012).

Based on those previous studies, theories and facts above, the researchers have then found that there have not been many research studies underlining a lot on investigating Indonesian EFL elementary students' problems in the learning of English speaking skill. Those problems should be observed in order to find the best solutions. When the problems are resolved properly, teaching speaking process can be done successfully. Therefore, the speaking skill of Indonesian children can be improved for them to be ready to face the future world. As related to the background of the study, the objective of conducting this study then is to describe the problems encountered by teachers in teaching speaking to Indonesian EFL elementary school students.

For teachers, the result of the study can help them to know the problems of teaching speaking for young learners. It also can help them to find the best 
solution for the problems in order to reach the success of learning. In addition to that, it is able to improve teachers' creativity and to help them in deciding the appropriate method in teaching speaking to EFL Elementary School Students. For students, this study can help them to get effective learning, especially English speaking, so that it will improve their speaking skills. For Schools, this study will help them develop their English teaching activity. It will also help them to prepare to be globally competitive students in the future. At last, the existence of this research can be a motivation and reference for the next researcher to conduct a study related to teaching speaking to EFL elementary school students.

\section{RESEARCH METHOD}

Study consists of a plan, which describes how, when and where the data will be analyzed and collected (Creswell, 2012). In conducting a study, it is important to decide the research design that will be used to get the data with specific purpose. This research belongs to descriptive qualitative study. It elucidates and describes the data gathered deeply. It portrays an accurately objective state or certain event based on the facts then accompanied by an attempt to draw general conclusions based on the obtained facts (Ramadhani \& Bahri, 2017). The detailed information on getting the sample of the study, procedures of collecting and analyzing the data will be discussed later on in this chapter.

\section{Population and Sample}

Population is a group of people or objects in one place, which can be used by a researcher as a sample in a study (Suryana, 2012). The population of this study was all elementary school teachers in Jepara, who are teaching English to the 3rd grade students. The sample, on the other hand, is sub group of people, items, or events from a large population that will be the main informant for a study (Gay et al., 2012). In this study, with convenient sampling techniques, the researchers sampled 3rd grade teachers from three different elementary schools in Kalinyamatan Jepara that still had English as one of the participants taught for the students. The reason for choosing 3rd grade teachers as the sample was because in this grade teachers should teach more complex English speaking material to the students. Furthermore, the respondents came from three different schools; so that more information obtained and problems experienced by each respondent could be compared. 


\section{Procedures for Collecting Data}

Some procedures were used for collecting the research data. They are preparing questionnaires and question lists, giving the questionnaire and conducting interviews, trustworthiness, and rigor. To determine the validity of the research instrument of qualitative data, the researchers, referring to Gay et al., (2012), used four criteria. They are: 1) Credibility, which is related to checking the tools and instruments before conducting the research; 2) Transferability, related to the result of the study that can be transferred to another context or setting; 3) Dependability, which is related to the examination of data analyzing process done by the expert; 4) Confirmability which is related to re-checking the data and information obtained from the interview.

Adapted from Muharram (2018); Bashir et al. (2008), the researchers then used content validity for the question list and questionnaire. The researchers used Simon's rubric with experts' judgment to ensure that the questionnaire and question list were appropriate to be used in the study. Furthermore, the data collected from the interview was transcribed and sent back to the interviewees for the validation. For the reliability, the researcher used an expert view to address the reliability of the data collecting instruments. To examine the reliability of data collection the researcher sent the transcribed interview to the interviewees then asked for their approval. Furthermore, the researchers re-checked the responses given from each participant and compared them to address the dependability of the research findings.

\section{Data Analysis}

Four steps were used in analyzing the data gathered. They are reading or memoing, describing, classifying, and interpreting (Gay et al., 2012). The first step to analyze the data was reading or memoing the data itself. Before starting the first step, the researchers transcribed the interview in advance. After transcribing the interview data, the researchers read it carefully and started to underline the most important information. Furthermore, the researchers made some notes in order to decide which information might be useful for the study.

The second step involved describing the data. The main objective of describing data is to find complete explanation of context, setting, and 
interactions of participants. The next step was classifying the data, which consisted in breaking down the data into several parts and putting it into more general groups or categories. The researchers also re-read the transcribed interviews and selected specific data to use and eliminate the other data that did not provide evidence for the topic to do further analysis.

The last step was data interpretation. This step aimed to find the meanings, connections, and links of the classified data. The researchers identified and abstracted important understandings from the data to know what is important, why it is important, and what the participants think about it. The researchers extended the analysis, connected research findings with previous studies and personal experience, and sought advice from friends or more experienced people in order to find the best result.

\section{RESULTS AND DISCUSSION}

In this section, the researchers discussed the research findings and then compared as well as connected them with some relevant theories. From the interview conducted, the researchers found different problems in the learning of English speaking skill faced by EFL elementary school students. Nuraini (2016) claims that the problems can be caused by certain factors: native language, age, exposure, motivation, and learners' autonomy.

In terms of native language, the teachers viewed that students' native languages, namely Indonesian and Javanese language, made it difficult for students to have English communication in class. They were not familiar with English language because they usually use Bahasa Indonesia and Javanese language every time. Teachers further said that in delivering the materials, they should translate it first so that students could understand and respond to the teacher. That finding was in line with the statement from Nuraini (2016) about students not being familiar with the target language when the teacher cannot understand the situation and find a solution for it, then teaching activities will be disturbed. The next students' problem was that they could not pronounce English words well. They often pronounced English words as the written form, whereas the English pronunciation was different. Teachers stated that students were already used to Indonesian writing and pronunciation, which had a 
similar sound. As stated by Nuraini (2016), English is a Foreign Language in Indonesia and it has a completely different linguistic aspect with students' native language, which becomes the fundamental factor in determining the success of speaking class. Therefore, it is difficult for teachers to improve students' speaking skill because they have to make students familiar with the difference of English writing and pronunciation. Language input is very essential, but it is not sufficient if not followed by interaction. Teachers (Ts) first should make students familiar with English. Ts can stimulate them to use English in class, giving them simple questions such as 'how are you?' and 'are you ready to start?' in the beginning of the lesson to gain their focus. Ts should use English as much as they can, to form new English communication habits for students. If it is possible, Ts can make an agreement with students to always use English during the lesson because students tend to do learning by doing. Those will help students find a new habit in using English, as well as improving their responsibility to keep using English as the medium for interaction. From the students' problems viewed by teachers related to native language, it can be concluded that the finding of the research was in line with the theory.

The second indicator becoming the EFL young learners' problems in the learning of English speaking was students' age. The researchers found different young learners' problems viewed by teachers related to the characteristics of 3rd grade students in the age of 8-9 years old. The problem was mostly about students' unstable mood and emotion. Teachers stated there were usually overactive and over-passive students in class. Teacher 2 further said that students in 3rd grade are one of the most difficult classes to teach because they are in transition between lower grade and higher grade. Some of them were interested in learning English, especially speaking, but it made them overly active at times, which led to bothering other friends. It is in line with Nuraini (2016), who states that young age is the best time to learn languages, but it also has some characteristics that potentially disturb the teaching and learning process. Additionally, Hanafi \& Sumitro (2020) stated that young learners are enthusiastic and curious in trying everything, but it can be a problem when they express it excessively. Another problem was that students in the 3rd grade still did not have the sense of having good English. They joined the English class because it was one of the school requirements that made them less enthusiastic 
about joining teaching activities. It was supported by the statement from Widodo \& Dewi (2019) about students' lack of attention and concentration on the lesson taught is because they are focusing on the language they use in their current concrete situation. They still had no intention that English is important for their future; therefore, they often feel unmotivated and become passive in class activities. Thus, it can be said that age also has a negative influence in teaching speaking for young learners. Teaching speaking for elementary students is not easy, but it is also not as difficult as it seems. Teachers should adapt to students' learning phase. They should know what students like nowadays and collaborate with the lesson. Teachers must try to use some learning methods to provide chances for students' different learning styles and provide simple videos or examples about the use of English in life to form students' understanding about the importance of English. Those activities can help gain students' interests in joining classroom activities and facilitate them with a comfortable learning environment.

The next young learners' issue was exposure. If we are talking about exposure, it is closely related to students' habit of getting language inputs, especially English. Exposure refers to how much students are exposed to the target language. As English is a foreign language in Indonesia, it can be said that students' chance of getting English exposure is lower than others who have English as their second language. From the interview, teachers observed that most students in their class have low English exposure. They further mentioned that students receive English only in the classroom and do not have chance to practice it outside. As stated by Sulistiyo (2016) the teaching and learning of English in Indonesia occurs only in formal classroom situations rather than in a daily basis. Students did not have opportunities to use English in their daily communication that made it difficult to improve their speaking. The quality and intensity of target language exposure have become very important in teaching speaking for young learners, and it is one of the most crucial obstacles found by teachers (Nuraini, 2016). Another problem as expressed by teachers was their difficulties in facilitating best target language exposure for their students. If we are talking about the quality of English exposure, it is surely one of teachers' responsibilities to give correct and appropriate English inputs for their students. This became a problem in teaching speaking for the 3rd grade students because teachers stated that they had difficulties in giving the best 
English inputs for their students. They said that sometimes they mispronounce some words or sentences that affect students' correctness in pronouncing English words. Teachers' difficulties in giving the best English inputs from the students should be given more attention, because English is more likely to be taught and learnt in the classroom. As stated by Suryati (2013), when the target language is not possible to be used outside the classroom, the language inputs in the classroom are very important. Therefore, we can conclude that exposure can be one of the problems in teaching speaking for young learners. Teachers can anticipate this problem by not making themselves the only source of exposure from students. There are a lot of English songs or cartoons that can be the original English inputs from native speakers. One thing that should be remembered for teachers is that they should constantly improve their skills and teaching methods because every generation has their own characteristics and specialties.

Another internal factor of young learners' problems was motivation. In the classroom context, motivation refers to students' interest and willingness in joining classroom activities. One of the factors that indicate students are having low motivation is that they feel reluctant to participate in teaching and learning activities (Nuraini, 2016). This problem was found by the researchers when doing interviews with teachers. Teacher 1, 2, and 3 expressed their opinion about motivation and said that students' motivation is one of the most essential elements in teaching speaking, especially for the 3rd grade students. Teachers said that students' lack of motivation became one of the hardest obstacles they found in teaching speaking. Teachers added that the number of active students participating in class activities was not more than 50 percent. The rest of the students ignored the teachers, some were talking with their friends, and the others were walking around the classroom. It was in line with Widodo \& Dewi (2019), young learners have a lot of reasons when they get bored, they will lose their focus, sleepy, keep silent, chat or play with friends, and be too lazy to do the activities. Teachers can face this problem using various teaching methods and activities for students. Language games such as picture games and guessing games can improve students' initiative to speak, as well as sharpen their critical thinking skill. Traditional games such as snakes and ladders can also be one of the activities used by teachers to maximize students' participation in the classroom. Another problem found is that students became shy to practice their 
speaking. They refused to respond whenever teachers called their names and asked them to practice in front of the class. This problem occurred when the teacher asked students to do some activities related to the lesson. This is in line with the statement from Nuraini (2016) about shyness becoming the major obstacle that makes students inactive in joining class activities. Another problem found was students were afraid of making mistakes. From the participants, they said that most of the students did not want to read or speak the language because they were worried about being teased by other friends, which made them lose their self-confidence. According to the teachers, those problems also occurred because students were not concentrating when the teacher was delivering the lesson. Therefore, students had low capability to comprehend the materials and could not practicing their speaking. As stated by Abrar (2016), students are mostly shy and afraid to practice their speaking due to their low competence. Teachers can solve this problem rewarding students. This should not always be done in every meeting, but giving rewards such a snack, or new pencils can improve students' courage to practice their speaking. This can improve their self-confidence and they cannot wait to practice their speaking in front of the class.

The last factor that could account for the young learners' problem in the learning of English speaking was learners' autonomy. The great challenge in teaching especially young learners is to make sure students keep learning and practicing outside the classroom. As we know, students in the 3rd grade are in the age of 8-9 years old and still need a lot of supervisors from teachers and their parents. But if we look again at the position that English is a foreign language in Indonesia it makes it more difficult for students to keep using English in their daily life. According to Nuraini (2016), in teaching speaking English as foreign language students must be ready with the use of target language inside or outside the classroom, but in reality, students find it difficult to do that. It was in line with the findings; teacher 1,2 , and 3 found that students' autonomy caused some problems, such as students' lack of initiative to speak. Other problems found that students forgot the lesson they had learned previously and they did not complete the assignment given from the teacher. Teachers stated that those problems took place because students did not get enough attention and supervision from their parents. According to Widodo \& 
Dewi (2019), students should be involved in using the target language, especially at home; unfortunately, not all parents can guide them. Teachers stated that most of the parents were working, and they could not give full attention to their children. Furthermore, not all parents understand and are able to speak English, which made it more difficult for students to use English outside school hours, which in turn made it challenging for teachers to decide which teaching methods and assignments were suitable for students. As supported by Widodo \& Dewi (2019), EFL students get the chance to practice their speaking only in the classroom with limited time and teachers have difficulties creating habits for students to use English in their daily life. From the findings, it can be concluded that learners' autonomy was one of the problems in teaching speaking to young learners. This problem becomes crucial because students' learning process is also the responsibility of their parents. As regards parents' supervision, teachers can make a group chat with the parents as their communication tool. They can also share the assignment directly to parents and remind them to guide their children to do the assignment. Parents can ask when they have difficulties in guiding their children; therefore teachers can help as well as making sure that students are practicing their English outside the school hours. Therefore, students can improve their speaking maximally with the great collaboration between teacher and parents.

From the previous explanation, we could see that those problems are related to one another. If we look back, we can find that students' native language influenced their exposure. Indonesian and Javanese are languages used by students in their daily life. In addition, English as a foreign language in Indonesia makes it even harder for students to get opportunities to hear, read, or speak English outside the classroom. Students did not have ready access to use English as a communication tool in their daily life. Therefore, they did not get enough exposure outside school hours and it affected their speaking performances. As stated by Widodo \& Dewi (2019), students do not have enough English input at home, which makes them less confident and hesitant about performing their speaking.

Other problems closely connected are students' age, motivation, and their learning autonomy. As we know, students in the 3rd grade still did not have the 
sense of having good English. They still did not understand the concrete use of English and it made them unmotivated in joining class activities. The condition became worse because they were in an unstable mood. They could be really active one day, but become so quiet on other days. Students also still needed a lot of supervision. Nuraini (2016) stated that students really need to keep practicing and speaking outside the classroom, and they surely need strong attention from their parents. On the other hand, EFL students have a lack of guidance especially from their parents, which causes them to forget the lesson they have learned. They also did not complete the assignment because their parents were too busy and did not have time to help their children to study.

Actually, students' behaviors toward the teaching of English as a foreign language (TEFL) are not always the same among elementary schools. Anwar and Kusumawarni (2018), who conducted a study in a private Islamic elementary school in Semarang even otherwise, found that young learners showed positive behaviors toward the teaching English as a foreign language, such as paying attention to the teacher's explanation, writing down and reading the material, actively and bravely asking questions to the teacher, and making the vocabulary list to be memorized.

\section{CONCLUSION}

Based on the results of the study, found are the factors accounting for the problems that EFL elementary school students face in the learning of English speaking. Those issues are closely related to their native language, age, exposure, motivation, and their learning autonomy. It can then be concluded that there are many challenges for teachers in teaching English speaking to young learners dealing with their varied issues. Students are supposed to get sufficient English language input both inside and outside the classroom. Also, students really need some encouraging words from the teachers and parents about the importance of English in their career and future. Furthermore, students need some supporting exposure from their environment, both inside and outside the classroom as a model of good examples in using the language appropriately. Last but not least, EFL young learners need to get their confidence, bravery, and initiative to participate in classroom activities. In doing 
so, their teachers, classmates and other people surrounding must work hand in hand to help them. Eventually, the researchers therefore would like to suggest for the next researchers to further investigate particularly the importance of language input from teachers on improving students' language skills.

\section{Acknowledgments}

The researchers would like to gratefully acknowledge the Dean and all teaching staff of Language and Communication Faculty, Universitas Islam Sultan Agung for their support and grant given in finishing this research.[rgt]

\section{REFERENCES}

Abrar, M. (2016). Teaching English problems: An analysis of EFL primary school teachers in Kuala Tungkal. In The 16th Indonesian Scholars International Convention (pp. 94-101).

Anwar, C., \& Kusumawarni, W. (2018). A Descriptive Analysis of Young Learners' Behaviours toward TEFL. Register Journal, 11(1), 79-100. https://doi.org/10.18326/rgt.v11i1.79-100

Anwar, C. (2016). Role-Play and Show-and-Tell in Grade 5 Students' Speaking Learning. EduLite: Journal of English Education, Literature and Culture, 1(1), 76. https://doi.org/10.30659/e.1.1.76-102

Arif, N. (2015). Removing English as compulsory subject from primary schools on the 2013 curriculum based on teachers' opinion. International Journal of Scientific and Research Publications, 5(8), 117-121. https://repository.unja.ac.id/id/eprint/1858

Bashir, M., Afzal, M. T., \& Azeem, M. (2008). Reliability and Validity of Qualitative and Operational Research Paradigm. Pakistan Journal of Statistics and Operation Research, 4(1), 35-45. https://doi.org/10.18187/pjsor.v4i1.59

Creswell, J. W. (2012). Educational Research: Planning, Conducting, and Evaluating Quantitative and Qualitative Research (4th ed.). http://library1.nida.ac.th/termpaper6/sd/2554/19755.pdf

Ellis, G. (2014). Young learners: Clarifying our terms. ELT Journal, 68(1), 75-78. https://doi.org/10.1093/elt/cct062

Freeman, D. L., \& Anderson, M. (2011). Techniques \& Principles in Language Teaching (3rd ed.). Oxford University Press. 
Gay, L. R., E. Mills, G., \& Airasian, P. (2012). Educational Research: Competencies for Analysis and Applications. http://library1.nida.ac.th/termpaper6/sd/2554/19755.pdf

Hanafi, I., \& Sumitro, E. A. (2020). Perkembangan Kognitif Menurut Jean Piaget Dan Implikasinya Dalam Pembelajaran. Alpen: Jurnal Pendidikan Dasar, 3(2). https://doi.org/10.24929/alpen.v3i2.30

Khetaguri, T., \& Albay, M. (2016). The Use of Drills in the Development of Speaking Skills. International Journal of Social Sciences \& Educational Studies, 3(1),

54-58. https://search.proquest.com/openview/a49cff0be78a11f87cbdd7ef09e9d4d0/1?p q-origsite $=$ gscholar\&cbl $=4672073$

Maili, S. N. (2018). Bahasa Inggris Pada Sekolah Dasar: Mengapa perlu dan mengapa dipersoalkan. JUDIKA (Jurnal Pendidikan Unsika), 6(1), 23-28. https://journal.unsika.ac.id/index.php/judika/article/view/1203/1013

Muharram, A. R. (2018). The English teachers' challenges and efforts in teaching by applying 2013 curriculum. Unpublished thesis. http://repository.unissula.ac.id/9001/

Nihat, S. Ş. (2010). Theory-practice dichotomy: Prospective teachers' evaluations about teaching English to young learners. Journal of Language and Linguistic Studies, $9(1)$ 76-99. https://www.researchgate.net/publication/273888609_Theorypractice_dichotomy_Prospective_teachers'_evaluations_about_teaching_English_to_yo ung_learners

Nofrion, N. (2018). NOFRION: Pentingnya Keterampilan Komunikasi di Era Revolusi Industri 4.0. https://doi.org/10.31227/OSF.IO/KRW28

Novianda, R. (2017). Teaching speaking by using picture strip stories. English Education Journal (EEJ), 8(3), 386-403. http://jurnal.unsyiah.ac.id/EEJ/article/view/8925

Nuraini, K. (2016). The barriers of teaching speaking English for EFL learners. ELLITE- Journal of English Language, Literature, and Teaching, 1(1), 7-13. http://jurnal.unmuhjember.ac.id/index.php/ELLITE

Ohashi, Y. (2015). Communicative language teaching, young learners' EFL, Play, Social constructivism 17. Fukuoka Jo Gakuin University Bulletin, 1, 17-30. https://ci.nii.ac.jp/naid/120005602273/en

Pratama, E. Y. (2015). Teacher's Strategies in Teaching Speaking to Young Learners. English Journal, 19-31. https://doi.org/DOI: http://dx.doi.org/10.32832/english.v9i2.243 
Ramadhani, P., \& Bahri, S. Y. (2017). E-ISSN 2528-746X Teachers' Problems in Teaching Speaking to Young Learners Putri. 2(February), 27-36.

Sadiku, L. M. (2015). The Importance of Four Skills Reading, Speaking, Writing, Listening in a Lesson Hour. European Journal of Language and Literature, 1(1), 29. https://doi.org/10.26417/ejls.v1i1.p29-31

Samosir, M., Rahayu, P., \& Donal, A. (2017). Improving students' vocabulary mastery through spelling bee game at fifth frade of SD swasta Kalampaian Kunto Darussalam. Jurnal Ilmiah Mahasiswa FKIP Prodi Bahasa Inggris, 3(1), 1-7. $\quad$ https://www.neliti.com/publications/110016/improving-studentsvocabulary-mastery-through-spelling-bee-game-at-fifth-grade-o

Seel, N. M. (2012). Problems: Definition, Types, and Evidence. In N. M. Seel (Ed.), Encyclopedia of the Sciences of Learning (pp. 2690-2693). Springer US. https://doi.org/10.1007/978-1-4419-1428-6_914

Sulistiyo, U. (2016). Learning English as a Foreign Language in an Indonesian University: A Study of Non-English Department Students' Preferred Activities Inside and Outside the Classroom. IJET (Indonesian Journal of English Teaching), 5(1), 1-26. https://doi.org/10.15642/ijet2.2016.5.1.1-26

Suryana. (2012). Metodologi Penelitian: Metodologi Penelitian Model Prakatis Penelitian Kuantitatif dan Kualitatif. Universitas Pendidikan Indonesia, 1-243. https://doi.org/10.1007/s13398-014-0173-7.2

Suryati, N. (2013). Developing an Effective Classroom Interaction Framework to Promote Lower Secondary School Students' English Communicative Competence in Malang, East Java, Indonesia. October, 323. http://hdl.handle.net/1959.13/1038812

Widodo, A., \& Dewi, S. R. (2019). Revealing Problems on Teaching English for Young Learners at Al - Azhar 55 Islamic Primary School Yogyakarta and How to Solve Them. Jurnal VARIDIKA, 30(2), 21-29. https://doi.org/10.23917/varidika.v30i2.7571

Zhu, D. (2012). Using Games to Improve Students' Communicative Ability. Journal of Language Teaching and Research, 3(4), 801-805. https://doi.org/10.4304/jltr.3.4.761-770. 